\title{
Influence of fat addition to feed mixtures on the rate of yolk sac resorption in chickens, blood and pancreas enzyme activity
}

\author{
Dorota Jamroz and T. Wertelecki
}

Wroclaw Agricultural University

Norwida 25/27, 50-375 Wroclaw, Poland

\begin{abstract}
The experiment was carried out on 476 Starbro chickens ( $\sigma$ ) divided into 4 groups, each in seven replications with 17 birds kept in cages in standard enviroment conditions. Chickens were fed mixtures contained $21.7 \%$ (starter), $20.0 \%$ (grower) crude protein and $9,6,3$ or $0 \%$ of rape seed oil. In $1,2,3,4,7,12,21$ and 35 days of life and $2 \mathrm{~h}$ after feeding chickens were wighted and killed. The resorption rate of yolk sac and changes of $\alpha$-amylase and lipase activity in blood serum and pancreas were estimated. The body weight of chickens was the best in group II, III and IV. Highest level of oil in mixture has reduced the growth after 21 days of life. Addition of fat to feed mixtures for chickens in their first 21 days of life influences the rate of yolk sac resorption, decreases feed intake and activity of $\alpha$-amylase in the pancreas, while conversely lipase activity in the pancreas increases together with increase in quantity of rape seed oil added.
\end{abstract}

KEY WORDS: blood enzymes, pancreas enzymes, fat, chickens

\section{INTRODUCTION}

The resorption rate of yolk sac contents and the development of the digestive tract of chickens substantially influences the utilization of nutrients. The concentration of carbohydrates, dietary fibre level and energy density in feeds can also modify the growth of the intestine tract, secretion and activity of endogenous enzymes (Jamroz and Wertelecki, 1998; Wertelecki and Jamroz, 1998a,b). In the present experiment, the rate of yolk sac resorption and the activity of amylase and lipase in the blood and pancreas have been investigated in chickens fed mixtures supplemented with different quantities of rape seed oil. 
TABLE 1

Composition of starter feed mixtures, $\%$

\begin{tabular}{lrrrr}
\hline & \multicolumn{3}{c}{ Groups } \\
\cline { 2 - 5 } & \multicolumn{1}{c}{ I } & II & III & IV \\
\hline Maize & 46.0 & 49.5 & 53.5 & 57.5 \\
Soyabean meal & 41.0 & 40.5 & 39.5 & 38.5 \\
Rape seed oil & $\mathbf{9 . 0}$ & $\mathbf{6 . 0}$ & $\mathbf{3 . 0}$ & $\mathbf{0 . 0}$ \\
Chalk & 1.5 & 1.5 & 1.5 & 1.5 \\
Dicalcium phosphates & 1.2 & 1.2 & 1.2 & 1.2 \\
Salt & 0.3 & 0.3 & 0.3 & 0.3 \\
Premix DKA & 1.0 & 1.0 & 1.0 & 1.0 \\
Crude protein & 21.7 & 21.8 & 21.8 & 21.7 \\
Ether extract & 11.5 & 8.7 & 5.8 & 2.9 \\
Crude fibre & 4.2 & 4.3 & 4.4 & 4.4 \\
Starch & 28.7 & 30.9 & 33.4 & 35.9 \\
Metabolizable energy, MJ/kg & 13.2 & 12.6 & 12.0 & 11.4 \\
Lysine, g/kg & 12.4 & 12.3 & 12.2 & 12.0 \\
Methionine, g/kg & 3.6 & 3.6 & 3.6 & 3.7 \\
Met + Cys, g/kg & 7.2 & 7.3 & 7.3 & 7.4 \\
Tryptophane, g/kg & 2.6 & 2.6 & 2.6 & 2.6 \\
Threonine, g/kg & 8.4 & 8.5 & 8.4 & 8.4 \\
Ca, g/kg & 9.6 & 9.6 & 9.5 & 9.5 \\
P-available, g/kg & 3.2 & 3.3 & 3.3 & 3.3 \\
Na, g/kg & 1.5 & 1.5 & 1.5 & 1.5 \\
\hline & & & & \\
\hline
\end{tabular}

TABLE 2

Body weight of chickens, g

\begin{tabular}{|c|c|c|c|c|}
\hline \multirow[b]{2}{*}{ Days of life } & \multicolumn{4}{|c|}{ Level of rape seed oil, \% } \\
\hline & $9(1)$ & $6(\mathrm{II})$ & $3(\mathrm{III})$ & $3($ III) \\
\hline \multirow[t]{2}{*}{1} & 39.1 & 38.9 & 39.4 & 39.5 \\
\hline & 3.38 & 3.42 & 2.18 & 2.55 \\
\hline \multirow[t]{2}{*}{2} & $46.3^{h}$ & $43.2^{\mathrm{a}}$ & $46.2^{\mathrm{h}}$ & $46.8^{\mathrm{b}}$ \\
\hline & 1.52 & 4.12 & 4.20 & 2.66 \\
\hline \multirow[t]{2}{*}{3} & 52.8 & 52.4 & 52.6 & 53.4 \\
\hline & 3.17 & 4.16 & 2.78 & 6.40 \\
\hline \multirow[t]{2}{*}{4} & $61.2^{\mathrm{AB}}$ & $63.7^{\mathrm{B}}$ & $56.6^{\mathrm{A}}$ & $60.3^{\mathrm{AB}}$ \\
\hline & 5.71 & 5.06 & 5.78 & 4.39 \\
\hline \multirow[t]{2}{*}{7} & 99.2 & 93.8 & 91.9 & 91.7 \\
\hline & 10.00 & 10.74 & 8.23 & 11.91 \\
\hline \multirow[t]{2}{*}{12} & 193.9 & 199.1 & 178.5 & 190.7 \\
\hline & 30.48 & 18.07 & 26.66 & 23.95 \\
\hline \multirow{2}{*}{21} & $457.1 \mathrm{~b}$ & $448.1^{\mathrm{ab}}$ & $404.5^{\mathrm{a}}$ & $434.2^{\mathrm{ab}}$ \\
\hline & 43.50 & 54.69 & 64.52 & 62.22 \\
\hline \multirow[t]{2}{*}{35} & $1161.1^{A}$ & $1402.4 \mathrm{~B}$ & $1386.9^{\mathrm{B}}$ & $1273.2^{\mathrm{AB}}$ \\
\hline & 176.52 & 85.84 & 146.54 & 264.16 \\
\hline
\end{tabular}

$\mathrm{a}, \mathrm{b}-$ significant at $\mathrm{P}<0.05 ; \mathrm{A}, \mathrm{B}-$ significant at $\mathrm{P}<0.01$ 


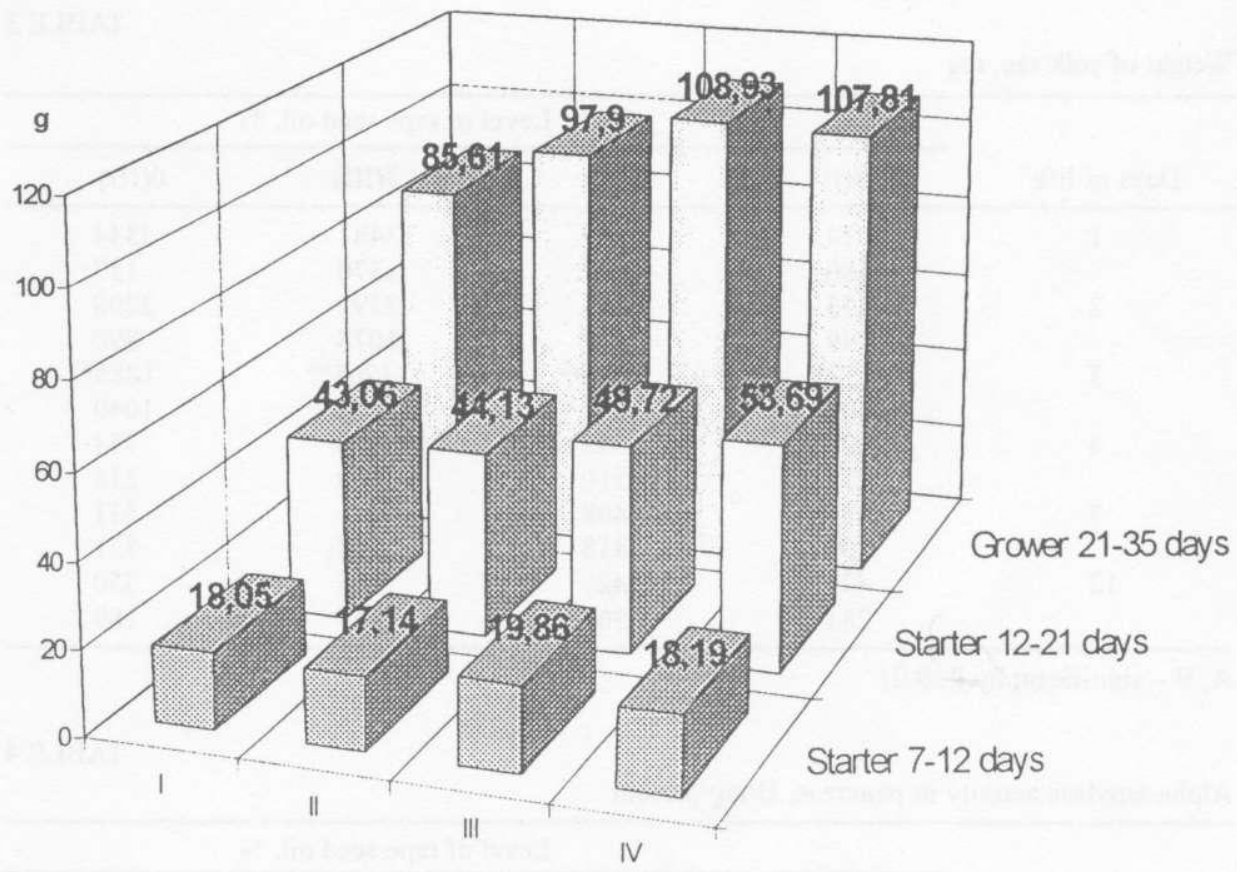

groups

Figure 1. Feed intake, g/head/day

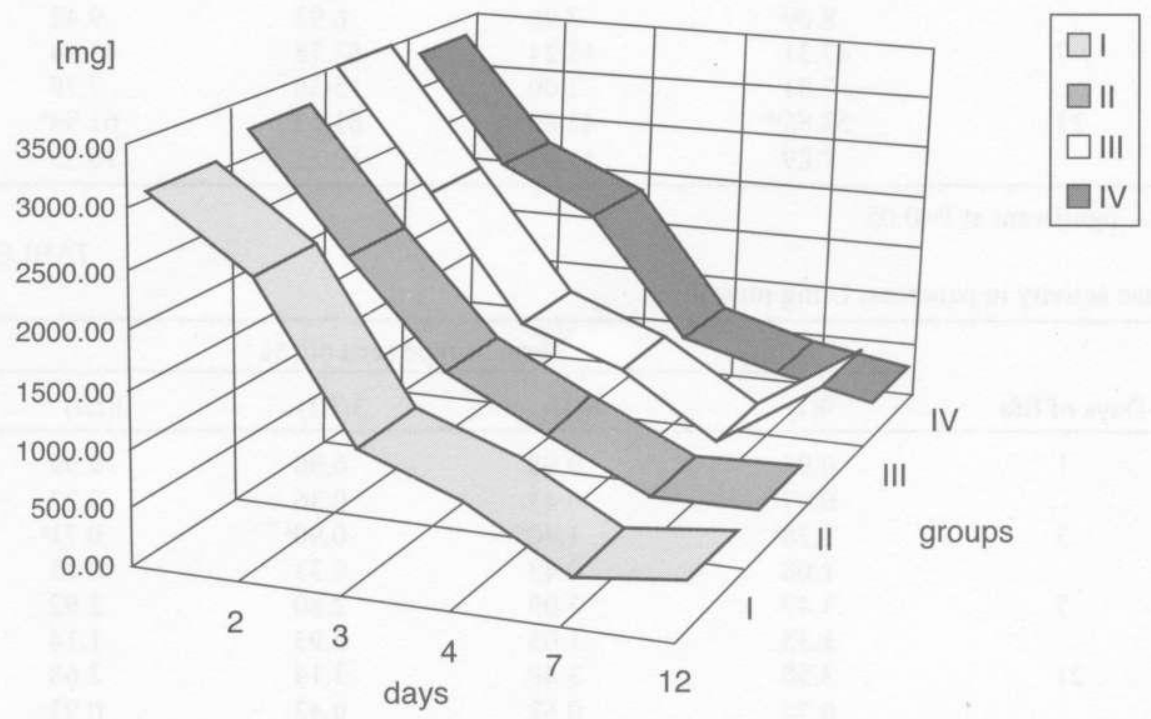

Figure 2. Resorption rate of yolk sac, mg 
TABLE 3

Weight of yolk sac, mg

\begin{tabular}{crccc}
\hline & \multicolumn{3}{c}{ Level of rape seed oil, $\%$} \\
\cline { 2 - 5 } Days of life & $9(\mathrm{I})$ & $6(\mathrm{II})$ & $3(\mathrm{III})$ & $0(\mathrm{III})$ \\
\hline 1 & 3074 & 3255 & 3481 & 3344 \\
& 1486 & 1257 & 1370 & 137 \\
2 & 2453 & 2223 & 2392 & 2298 \\
& 749 & 762 & 1078 & 890 \\
& $1147^{\mathrm{A}}$ & $1286^{\mathrm{AB}}$ & $1265^{\mathrm{AB}}$ & $1885^{\mathrm{B}}$ \\
4 & 404 & 461 & 485 & 1040 \\
& 829 & 848 & 930 & 774 \\
7 & 279 & 310 & 520 & 238 \\
& 326 & 308 & 371 & 511 \\
& 259 & 426 & 168 & 521 \\
& 429 & 368 & 983 & 350 \\
& 281 & & 1767 & 189 \\
\hline
\end{tabular}

A, B - significant by $\mathrm{P}<0.01$

TABLE 4

Alpha-amylase activity in pancreas, $\mathrm{U} / \mathrm{mg}$ protein

\begin{tabular}{|c|c|c|c|c|}
\hline \multirow[b]{2}{*}{ Days of life } & \multicolumn{4}{|c|}{ Level of rape seed oil, \% } \\
\hline & $9(\mathrm{I})$ & 6(II) & 3(III) & $0(\mathrm{III})$ \\
\hline \multirow[t]{2}{*}{1} & 28.66 & 32.48 & 27.52 & 30.91 \\
\hline & 3.41 & 9.09 & 6.24 & 4.22 \\
\hline \multirow[t]{2}{*}{3} & 37.00 & 35.93 & 36.28 & 39.99 \\
\hline & 8.09 & 7.96 & 6.97 & 9.42 \\
\hline \multirow[t]{2}{*}{7} & 47.31 & 45.24 & 52.78 & 43.94 \\
\hline & 7.81 & 7.00 & 15.36 & 7.79 \\
\hline \multirow[t]{2}{*}{21} & $53.85^{\mathrm{ab}}$ & $43.80^{\mathrm{a}}$ & $61.63^{\mathrm{b}}$ & $61.94^{b}$ \\
\hline & 7.89 & 11.87 & 10.31 & 16.33 \\
\hline \multicolumn{5}{|c|}{$\mathrm{a}, \mathrm{b}-$ significant at $\mathrm{P}<0.05$} \\
\hline \multicolumn{5}{|c|}{ Lipase activity in pancreas, $\mathrm{U} / \mathrm{mg}$ protein } \\
\hline \multirow[b]{2}{*}{ Days of life } & \multicolumn{4}{|c|}{ Level of rape seed oil, $\%$} \\
\hline & $9(\mathrm{I})$ & 6(II) & 3(III) & $0(\mathrm{III})$ \\
\hline \multirow[t]{2}{*}{1} & 0.95 & 0.98 & 0.90 & 0.99 \\
\hline & 0.07 & 0.43 & 0.36 & 0.22 \\
\hline \multirow[t]{2}{*}{3} & $1.78^{b}$ & $1.40^{\mathrm{ab}}$ & $0.90^{\mathrm{a}}$ & $0.71^{\mathrm{a}}$ \\
\hline & 1.08 & 0.43 & 0.33 & 0.13 \\
\hline \multirow[t]{2}{*}{7} & 3.49 & 3.09 & 2.80 & 2.92 \\
\hline & 1.35 & 1.05 & 0.93 & 1.14 \\
\hline \multirow[t]{2}{*}{21} & 3.50 & 3.40 & 3.14 & 2.68 \\
\hline & 0.72 & 0.62 & 0.43 & 0.93 \\
\hline
\end{tabular}

a, $\mathrm{b}-$ significant by $\mathrm{P}<0.05$ 


\section{MATERIAL AND METHODS}

The experiment was carried out on 476 Starbro chickens 1 which were divided into 4 groups, each in seven replications with 17 birds. The birds were kept in cages under standard conditions. The chickens were fed mixtures containing $21.7 \%$ (starter), $20.0 \%$ (grower) crude protein and 9, 6, 3 or $0 \%$ of rape seed oil (Table 1). Two $\mathrm{h}$ after feeding some chickens from each group were weighed and killed at 1 , $2,3,4,7,12,21$ and 35 days after hatching: i.e., 21 birds from each group on the $1^{\text {st }}$ day and 14 birds from each group on the other days. The resorption rate of the yolk sac and changes of $\alpha$-amylase and lipase activity in blood serum and pancreas were estimated. The yolk sac was freeze-dried and the crude protein and fat content were analysed. The amylase activity in blood serum and the pancreas was determined according to the Enzyline $\alpha$-Amylase RTU - kinetic determination of $\alpha$-amylase activity (in vitro diagnostic test no. $63115 / 63116 / 63$ 117 bioMerieux sa); - the lipase activity was determined by Enzyline Lipase Color - kinetic determination of lipase activity (in vitro diagnostic test $\mathrm{nr}$ 63108 / 63109 bioMerieux sa).

\section{RESULTS}

The body weight of chickens was the best in group II, III and IV. The highest level of oil in the diet reduced the growth rate after 21 days of age (Table 2). The high fat addition has reduced the feed intake (Figure 1).

The slowest resorption of yolk sac was observed in the period from the $1^{\text {st }}$ to $7^{\text {th }}$ day after hatching in the chicks from group IV ( $0 \%$ of oil). Chickens fed mixtures without oil supplement absorbed the yolk sac content slowly but precisely (Table 3, Figure 2). Pancreatic $\alpha$-amylase activity changed in relation to body weight, and increased from $29,9 \mathrm{U}$ on day 1 to $55,3 \mathrm{U} / \mathrm{mg}$ protein on the $21^{\text {st }}$ day of life $(\mathrm{P}<0.05)$. Higher pancreatic amylase activity was found in chickens from groups III and IV compared to groups I and II $(\mathrm{P}<0.05)$. Lipase activity in the pancreas increased together with the age of the chickens. The highest activity was present in birds from groups I and II, i.e., in chickens fed the highest level of oil supplement mixtures (Table 5). These results suggest that fat addition to the feed increases pancreatic lipase activity, which thus increases the chances of fat degradation.

\section{CONCLUSIONS}

Addition of fat to feed mixtures for chickens in their first 21 days of life influences the rate of yolk sac resorption, decreases feed intake and activity of $\alpha$-amy- 
lase in the pancreas, while conversely lipase activity in the pancreas increases together with increase in quantity of rape seed oil added.

\section{REFERENCES}

Jamroz D., Wertelecki T., 1998. Effect of different dose of rape seed oil meal and enzymes supplementation on the yolk sac resorption and digestive tract development in chickens. European Poultry Conference, Jerosolima (in press)

Wertelecki T., Jamroz D., 1998a.Yolk sac resorption rate, digestive tract development as well as changes of $\alpha$-amylase activity in chickens depending on their keeping system (part I and II). Book of Abstracts of the International Conference "Current Problems of Breeding, Health and Production of Poultry", Česke Budejovice, Czech Republic, p. 203

Wertelecki T., Jamroz D., 1998b. Yolk sac resorption, digestibility tract development and $\alpha$-amylase activity changes in serum of chicken broilers. European Poultry Conference, Jerosolima (in press) 